\title{
Effect of incorporation of antioxidants on the chemical, rheological, and sensory properties of probiotic petit suisse cheese
}

\author{
E. P. R. Pereira, ${ }^{*}$ R. N. Cavalcanti, ${ }^{*}$ E. A. Esmerino,† R. Silva,† L. R. M. Guerreiro, ${ }^{\star}$ R. L. Cunha, ${ }^{*}$ \\ H. M. A. Bolini, ${ }^{*}$ M. A. Meireles, ${ }^{*}$ J. A. F. Faria, ${ }^{*}$ and A. G. Cruz ${ }^{1}$ \\ *Universidade Estadual de Campinas (UNICAMP), Faculdade de Engenharia de Alimentos, Cidade Universitária Zeferino Vaz, 13083-862, \\ Campinas, São Paulo, Brazil \\ †Instituto Federal de Educação, Ciência e Tecnologia do Rio de Janeiro, Mestrado Profissional em Ciência e Tecnologia de Alimentos, Maracanã, \\ 20270-021 Rio de Janeiro, Brazil
}

\begin{abstract}
This work investigated the effect of the addition of different antioxidants (ascorbic acid, glucose oxidase, cysteine, and jabuticaba extract) on the rheological and sensorial properties of the probiotic petit suisse cheese. Absence of influence of the antioxidants at the physicochemical characteristics of the petit suisse cheese was observed. Overall, the petit suisse cheeses presented weak gel characteristics and behaved as pseudoplastic material, except for control. All treatments exhibited a thixotropic non-Newtonian behavior; however, higher hysteresis area was obtained for control sample, which indicates that antioxidants incorporated to petit suisse had a protective effect on the typical thixotropic behavior of the Quark gel. The commercial sample presented higher scores for all aspects by consumers, whereas the probiotic petit suisse samples presented opposite behavior. Projective mapping was able to generate a vocabulary where the sample containing jabuticaba skin extract obtained by supercritical extraction was characterized by the panelists as presenting grape flavor and purple color.
\end{abstract}

Key words: jabuticaba skin extract, probiotic petit suisse cheese, rheology, projective mapping

\section{INTRODUCTION}

Petit suisse cheese has emerged as a suitable food matrix for addition of probiotics (Esmerino et al., 2013) because it is a fresh cheese with a limited shelf life and thus must be kept under refrigerated storage (Cruz et al., 2009) and is manufactured by several dairy factories. Although cheese is considered an adequate food matrix for probiotic, the processing of petit suisse has an intrinsic step of mixing where oxygen is added. In

Received April 12, 2015.

Accepted November 2, 2015.

${ }^{1}$ Corresponding author: food@globo.com this sense, this step can affect the survival of probiotics as they are sensitive to the presence of oxygen, once they have anaerobic or microaerophilic metabolism (Tripathi and Giri, 2014).

Indeed, the exposure to oxygen during the intrinsic operations of processing and storage of dairy products represents a major technological barrier with respect to the viability of probiotic bacteria (Granato et al., 2010; Van den Ende et al., 2011). The addition of antioxidants to improve probiotic survival during the storage of the product can be an potential alternative, with positive findings reported in fruit juices (Shah et al., 2010), and yogurt (Cruz et al., 2012, 2013a,b, 2015). However, as any functional food, the addition of probiotic microorganisms must not alter the physicochemical, sensory, or structural characteristics of a food (Cruz et al., 2010). In this context, a probiotic cheese must have the same characteristics of a conventional cheese [i.e., the incorporation of probiotics should not result in an overall product quality loss (Karimi et al., 2012)]. In this research, the effect of several antioxidants on the physicochemical and rheological characteristics as well as the sensory profiling using a consumer-driven approach as projective mapping of probiotic petit suisse cheese were evaluated.

\section{MATERIALS AND METHODS}

\section{Materials}

The following commercial ingredients were used for the preparation of the probiotic petit suisse: pasteurized milk (3.0\% fat, Dairy Atilatte Ltda., Itatiba, Brazil), crystal sugar (Cosan Alimentos SA, Tarumã, Brazil), sterilized cream (25\% fat, Nestlé Brazil Ltda., Aracatuba, Brazil), and Hexus and Petit Suisse 500 powder (Hexus Food Ingredients, Portão, Brazil) composed of milk protein concentrate, whey protein concentrate, gelatin, and guar gum. Streptococcus thermophilus (TA 040, Danisco, Dangé, France) was used as starter culture, and Lactobacillus acidophilus (LA C4, Danisco) 
and Bifidobacterium animalis ssp. lactis (DN 173-010, Danisco) were used as probiotic cultures. The following antioxidants were used: ascorbic acid (L-ascorbic acid PA, Casa da Química Ind. e Com. Ltda., Diadema, Brazil), cysteine (L-cysteine hydrochloride PA, Labsynth Produtos para Laboratórios Ltda, Diadema, Brazil), glucose oxidase containing glucose (Glucomax CO, Prozyn, São Paulo, Brazil, and D-glucose anhydrous PA, Labsynth Produtos para Laboratórios Ltda., respectively), and jabuticaba bark extract obtained by supercritical extraction. For sensory evaluation, strawberry flavor was added to the samples (Industrial Duas Rodas, Jaraguá do Sul, Brazil). The samples were packed in polystyrene flasks with low-density polyethylene screw-capped tubes with a capacity of $50 \mathrm{~mL}$ purchased from a packaging company (Ânfora Embalagens, Acessórios e Utilidades em Geral Ltda., Campinas, Brazil).

\section{Experimental Design}

Five petit suisse cheeses with antioxidants were manufactured. Antioxidants previously reported in previous studies, such as ascorbic acid, glucose oxidase + glucose, and cysteine (TAA, TGO, and TCI, respectively), were added with concentrations previously reported; the use of glucose together with glucose oxidase was needed to improve the action of the enzyme $(250,62.32$, and 29 mg/kg; Dave and Shah, 1997a,b; Cruz et al., 2010, 2012, $2013 \mathrm{~b})$. No study reported the addition of jabuticaba skin extracts in probiotic petit suisse cheese; however, preliminary experiments indicated the use of $5,000 \mathrm{mg} /$ $\mathrm{kg}$ (Michael et al., 2010). This sample was coded as TJE. Finally, probiotic petit suisse without antioxidant was also manufactured (TC). Table 1 reports the treatments and the amount of each antioxidant used.

\section{Jabuticaba Bark Extract Preparation}

The jabuticaba bark extract was extracted by supercritical extraction using a system equipped with 415$\mathrm{mL}$ extraction cell $(3.4 \mathrm{~cm}$ internal diameter and 37.5 $\mathrm{cm}$ height), which was completely filled with the residue from jabuticaba jelly production, obtained from Fazenda Santa Maria (Campinas, Brazil). The process was carried out at $60^{\circ} \mathrm{C}$ and 300 bar using carbon dioxide and water as solvents $(80: 20, \mathrm{wt} / \mathrm{wt})$. The extraction conditions were static extraction time $\left(t_{\mathrm{s}}=15\right.$ $\min )$ and dynamic extraction time $\left(t_{D}=240 \mathrm{~min}\right)$, carbon dioxide flow rate $\left(\mathrm{Q}_{\mathrm{CO}_{2}}=15.18 \mathrm{~g} \cdot \mathrm{min}^{-1}\right)$, and water flow rate $\left(\mathrm{Q}_{\mathrm{H}_{2} \mathrm{O}}=3.79 \mathrm{~g} \cdot \mathrm{min}^{-1}\right)$, amount of material in the extraction cell $(\mathrm{F} \cong 280 \mathrm{~g})$ and the solvent to raw material mass ratio and was kept constant $(\mathrm{S} / \mathrm{F}$ $\cong 16 \mathrm{~m} / \mathrm{m}$ ). The removal of the water from the extract was performed on a bench lyophilizer (Liotop L101, Liobras, São Carlos, Brazil) connected to a vacuum pump (Heidolph, Rotavac, Viertrieb, Germany). The extraction was replicated until it reached the required amount to be used in petit suisse samples.

\section{Probiotic Petit Suisse Processing}

The starter culture $S$. thermophilus (TA 040, Danisco), and the probiotic cultures Lactobacillus acidophilus (LA C4 Danisco) and Bifidobacterium lactis (DN 173010 Danisco) were used in all treatments and added in concentrations about 6,7 , and $7 \mathrm{log} \mathrm{cfu} / \mathrm{g}$, respectively, in accordance with the supplier's instructions. During the storage time $(28 \mathrm{~d})$, all treatments presented viable counts above $6 \mathrm{log} \mathrm{cfu} / \mathrm{g}$ for L. acidophilus and Bifidobacterium lactis, which it is a requisite for food products to be considered probiotic.

In a stainless steel container, pasteurized whole milk (Xando, Campinas, Brazil, about 3\% wt/wt fat), crystal sugar (União, Rio de Janeiro, Brazil, 10.5\% wt/ vol), and Hexus Petit Suisse $500 \mathrm{mix}$ (6.0\% wt/vol) were mixed under manual shaking for $1 \mathrm{~h}$ for hydration. After this period, sterilized cream $(5.0 \% \mathrm{wt} / \mathrm{vol})$ was added and the mixture was subjected to heated treatment at $90 \pm 5^{\circ} \mathrm{C}$ for $5 \mathrm{~min}$. The mixture was cooled to $37 \pm 5^{\circ} \mathrm{C}$, and lyophilized commercial cultures were added (Direct Vat Set) at a concentration of $30 \mathrm{mg} \cdot \mathrm{L}^{-1}$ (3\% wt/vol) for Streptococcus thermophilus and $50 \mathrm{mg} \cdot \mathrm{L}^{-1}(5 \% \mathrm{wt} / \mathrm{vol})$ for L. acidophilus and $B$. lactis. The product was incubated at $37^{\circ} \mathrm{C}$ until $\mathrm{pH} 4.7$ to 4.9 (approximately $6 \mathrm{~h}$ ). After fermentation, petit suisse was divided into 5 portions and the antioxidants, previously dissolved into water, were added under stirring. Strawberry flavor was added $(1.0 \%$, wt/wt) to the samples for the sensory tests. The treatments were

Table 1. Probiotic Petit Suisse cheese added with antioxidants ${ }^{1}$

\begin{tabular}{llllll}
\hline Item & TC & TAA & TGO & TCI & TJE \\
\hline Antioxidant & - & Ascorbic acid & Glucose oxidase + glucose & Cysteine & Jabuticaba extract \\
Concentration $\left(\mathrm{mg}^{\mathrm{k}} \mathrm{kg}^{-1}\right)$ & & 250 & 62.32 & 280 & 5,000 \\
\hline 1 & & &
\end{tabular}

${ }^{1}$ TC, TAA, TGO, TCI, TJE = probiotic petit suisse cheese without antioxidant (control), with ascorbic acid, glucose oxidase, cysteine, and jabuticaba extract, respectively. 
placed in the polystyrene vials and stored under refrigeration $\left(4 \pm 1^{\circ} \mathrm{C}\right)$ for $28 \mathrm{~d}$.

\section{Chemical Composition}

Moisture, fat, and protein contents were determined in triplicate after 1 and $28 \mathrm{~d}$ of refrigerated storage (4 $\left.\pm 1^{\circ} \mathrm{C}\right)$. Moisture content was determined by drying method at $105 \pm 1^{\circ} \mathrm{C}$ until constant weight (about 15 h). Protein was determined as total nitrogen by Kjeldahl method, and the nitrogen content was multiplied by the factor 6.38 to convert nitrogen to protein (AOAC International, 2006). Fat content was determined using Bligh and Dyer (1959) method.

\section{Rheological Measurements}

The viscoelastic properties of the petit suisse cheese formulations were measured in a controlled tension rheometer (model AR 1500ex, TA Instruments, New Castle, DE) to give an overall idea of the effect of each antioxidant in the cheese matrix. The flow curves and the dynamic oscillatory assays were performed using a stainless steel cone-plate geometry, in which the rotating cone was $60 \mathrm{~mm}$ in diameter, and cone angle of $2^{\circ}$ with a gap of $0.5 \mathrm{~mm}$. The petit suisse samples were loaded on the inset plate and left to rest for 10 min at $4 \pm 0.1^{\circ} \mathrm{C}$ for structure recovery. Temperature maintenance was achieved with Physica TEK 150P temperature control and measuring system. Analysis was performed in triplicate for each formulation at 1 and $28 \mathrm{~d}$ of refrigerated storage at $4 \pm 1^{\circ} \mathrm{C}$.

For the dynamic oscillatory trials, a strain amplitude sweep test (0.01-10\%) at a fixed frequency of $1 \mathrm{~Hz}$ (data not shown) was previously performed to establish the linear viscoelastic regimen, according to Veiga et al. (2000). Frequency sweeps were carried out in the range of 0.01 to $10 \mathrm{~Hz}$ within the linear viscoelasticity domain for each sample. The storage $\left(\mathbf{G}^{\prime}\right)$ and loss $\left(\mathbf{G}^{\prime \prime}\right)$ moduli were measured, and the loss angle $(\tan \delta)$ was calculated as $\tan \delta=\mathrm{G}^{\prime \prime} / \mathrm{G}^{\prime}$.

The flow curves were obtained using an up-down-up steps program. To evaluate and eliminate the thixotropy, the shear rate varied from 0 to $300 \mathrm{~s}^{-1}$. The shear time-dependence (thixotropic behavior) was estimated using the area between the curves of first and third shear cycle (hysteresis; Steffe, 1996; Sato and Cunha, 2007; Silva et al., 2010; Perrechil et al., 2010; Cruz et al., 2013b; Kuhn et al., 2014). The third flow curve data were fitted to the Herschel-Bulkley model (equation [1]) by a nonlinear regression analysis using Statistica 5.0 (Statsoft, Tulsa, OK) according to previous works (Silva et al., 2010; Kuhn et al., 2014):

$$
\sigma=\sigma_{0}+k(\dot{\gamma})^{n},
$$

where $\sigma$ is the shear stress $(\mathrm{Pa}), \sigma_{0}$ is the yield stress $(\mathrm{Pa}), k$ is the consistency index $\left(\mathrm{Pa} \cdot \mathrm{s}^{\mathrm{n}}\right), \dot{\gamma}$ is the shear rate $\left(\mathrm{s}^{-1}\right)$, and $n$ is the flow behavior index (dimensionless).

\section{Projective Mapping}

Sensory tests were performed just after $2 \mathrm{~d}$ of refrigerated storage $\left(4 \pm 1^{\circ} \mathrm{C}\right)$. A commercial, well-established strawberry-flavored petit suisse sample without probiotic $(5.2 \%$ protein, $1.3 \%$ fat, $6.5 \%$ carbohydrates, $\% \mathrm{wt} / \mathrm{wt}$, as indicated on the label) was added. It is interesting to evaluate the performance of probiotic foods with commercial ones belonging to the same category, as the latter are usually consumed and were previously submitted to previous tests by dairy processors (Cruz et al., 2010). The project was submitted and approved by the Research Ethics Committee under number $1124 / 2010$. Before each test, the assessor received an informed consent form, which was signed and filed.

Consumers (60 consumers, aged between 20 and 35 yr, $70 \%$ female and $30 \%$ male) evaluated the samples in relation to appearance, aroma, flavor, texture, and overall impression using a hedonic scale of 9 points $(1=$ extremely disliked; $5=$ not liked nor disliked; nine $=$ extremely liked; Morais et al., 2014; Paixão et al., 2014), and purchase intention of samples was determined using a binary scale using yes or no options (Cruz et al., 2011; Gaze et al., 2015). Samples ( $\approx 20$ g) were presented in monadic form in disposable plastic cups coded with random 3-digit numbers in balanced complete block, which remained under refrigeration (4 $\pm 1^{\circ} \mathrm{C}$ ) until the time of analysis.

The sensory profile of the product was determined using the projective mapping descriptive technique with 30 consumers (18 women, 12 men, aged 18-34 yr). Projective mapping is a qualitative data collection technique used to create a projection of a product as a way to better understand it in relation to another, or to understand consumers and their reactions. Similarities and differences are represented by the distance between each product (Jervis and Drake, 2014). Projective mapping has been used in several studies to characterize various food products, such as yogurt (Cruz et al., 2013b), cheese pie (Marcano et al., 2014), bologna (Santos et al., 2013), and tea (Kim et al., 2013).

Samples were stored under refrigeration $\left(4 \pm 1^{\circ} \mathrm{C}\right)$ until time of analysis, and $\approx 20 \mathrm{~g}$ was served simultaneously in disposable plastic cups coded with random 3 -digit numbers. The panelists were asked to describe each sample with respect to appearance, aroma, flavor, 
and texture. They were also asked to describe each attribute using a maximum of 4 words, avoiding hedonic descriptions. Subsequently, the assessors were asked to place each sample on an A4 paper sheet $(21 \times 29.7 \mathrm{~cm})$ so that the distance between samples representing their similarity (i.e., similar samples should be located near one another and different samples would be located far apart).

\section{Statistical Analysis}

Two replications of the petit suisse cheese processing were performed, which were $1.0 \mathrm{~kg}$ of each treatment in each replication; the sensory profiling was performed only in the second trial. All the physicochemical and rheological analyses were performed in duplicate.

Fixed effect one-way ANOVA was used to determine significant differences between the petit suisse cheeses regarding the rheological analysis, physicochemical characteristics, and consumer acceptance test. In sequence, the Tukey mean comparison test was used to determine the difference between means, considering a 95\% significance level. The purchase intention was evaluated by the frequency of occurrence of positive/ negative responses. The SAS software was used for this purpose (SAS Institute Inc., Cary, NC).

Multiple factor analysis (MFA) was used for evaluation of the projective map data. The MFA combines several data tables of different type variables. Within a table, the variables must be of the same nature (quantitative or qualitative) and integrate different tables of variables describing the same observations (Worch, 2013). Hierarchical cluster analysis (HCA) was used for sample groups with similar characteristics being used the coordinates in the first and second dimension of sensory maps produced by MFA. Euclidean distances (dissimilarity), Ward's method (method of agglomeration), and automatic truncation were considered (Varela and Ares, 2012) during the application of HCA. All data were analyzed by XLSTAT for Windows version 2013.5 (Addinsoft, Paris, France).

\section{RESULTS AND DISCUSSION}

\section{Chemical Composition}

Overall, influence was not observed of the antioxidants at the chemical composition of the petit suisse cheeses among the samples and along the refrigerated storage $(P<0.05)$. Regarding the moisture content, all samples presented values greater than $70 \% \mathrm{wt} / \mathrm{wt}$, whereas for the protein and fat contents, the values ranged between 6.34 to 6.18 and 4.42 to $4.16 \%$ wt/wt, respectively. Indeed, it is desirable that the addition of any compound, as antioxidants, do not alter the physicochemical composition of the petit suisse, preserving their characteristics with regard to macronutrients. Similar results have been reported by other authors on other fresh cheeses such as Minas Frescal (FritzenFreire et al., 2010).

\section{Rheological Measurements}

Petit suisse cheese presents a viscoelastic behavior (i.e., when it is subjected to a certain deformation, part of the mechanical energy is stored as elastic energy while part of is lost; Lucey et al., 2003). The viscoelastic properties of foods can be determined by oscillatory dynamic tests, in which a low amplitude are applied and $\mathrm{G}^{\prime}$ and $\mathrm{G}^{\prime \prime}$ moduli can be measured (Lucey et al., $2003)$. The storage or elastic modulus $\left(G^{\prime}\right)$ is defined as a measure of the energy stored per oscillation cycle, and can be used as an index of stiffness or elasticity of cream cheese (Fröhlich-Wyder et al., 2009). In this sense, the loss or viscous modulus $\left(\mathrm{G}^{\prime \prime}\right)$ is a measure of dissipated/lost energy per cycle of oscillation (Fox et al., 2000).

Figures $1 \mathrm{~A}$ and $1 \mathrm{~B}$ exhibit the mechanical spectrum of the petit suisse samples with respect to storage $\mathrm{G}^{\prime}$ and $\tan \delta$, respectively. As can be seen in Figure 1A, the storage modulus was less dependent on the frequency, which is a characteristic of weak gels typical of petit suisse cheese and yogurt matrices (Veiga et al., 2000). The loss tangent, defined as $\tan \delta=\mathrm{G}^{\prime \prime} / \mathrm{G}^{\prime}$ (Fox et al., 2000), showed a weak dependence on the frequency for all samples (Figure 1B). Independent of storage time, all petit suisse samples showed $\tan \delta$ values smaller than unity, indicating a dominance of the elastic properties $\left(\mathrm{G}^{\prime}\right)$ over viscous flow $\left(\mathrm{G}^{\prime \prime}\right)$. This indicates the material behaves more like a solid than as a fluid (i.e., the deformations is essentially elastic or recoverable; Cruz et al., 2013b).

The rheological behavior of cheese is related to its composition, microstructure (structural arrangement of its components), physicochemical state of food components (fat coalescence, hydrolysis and hydration of the para-casein matrix, level of intermolecular attractions between para-casein molecules, and so on) and its macrostructure, which reflects the presence of heterogeneities as the junction breaks and cracks of curd granules. In the case of petit suisse, the gel consists essentially of a particulate calcium phosphate para-casein matrix composed of interconnected and overlapping strands of partially fused para-casein aggregates, in turn formed from fused para-casein micelle (O'Callaghan and Guinee, 2004).

The addition of antioxidant has affected significantly the petit suisse samples resulting in smaller values for 
viscous and elastic modulus. The mechanical spectra showed that the curves of the sample TC (control) exhibited higher values of $\mathrm{G}^{\prime}$ and $\mathrm{G}^{\prime \prime}$, when compared with the other treatments, regardless of storage time. This behavior suggests that the addition of antioxidants interferes with the formation of the protein network, decreasing the gel strength. This behavior might be related to petit suisse cheese manufacturing of the quark gel, which may be broken down due to severe shearing conditions during the incorporation of antioxidants as observed by Ramírez-Santiago et al. (2012). It is worth mentioning that no study about the effects of antioxidant additives on viscoelastic properties of petit suisse cheese is found in the literature; thus, the comparison of our results with literature data is a difficult task. Likewise, El Samh et al. (2013) found that probiotic yogurts flavored with strawberry, black carrot, and pumpkin extracts exhibited a decrease in viscosity in comparison to control samples, as demonstrated in our study. Among the treatments supplemented with antioxidants, the samples TAA and TJE showed the highest $G^{\prime}$ and $G^{\prime \prime}$, with rheological profile closest to the control, thus presenting itself as the most promising functional additives. The storage time also affected the $G^{\prime}$ and $G^{\prime \prime}$ values, which increased after $28 \mathrm{~d}$. This increase was more pronounced in the samples containing antioxidant agents. However, among the formulations containing antioxidants, the treatments TGO and TJE showed higher stability over the $28 \mathrm{~d}$ of storage. Such behavior may be associated with the large number of protein interactions and rearrangements occurring during storage. The same phenomenon was observed by Ramírez-Santiago et al. (2012) who have reported that it may be a consequence of restructuring of the gel network during quiescent storage, after severe shearing conditions occurred during incorporation of the antioxidants.

According to the flow curves in Figure 2, all treatments exhibited a thixotropic non-Newtonian behavior. It is known that in fragile particulate structures, the 3 -dimensional network is completely destroyed by shear rates (Steffe, 1996), as is the case for Quark cheese.

As can be seen in Figure 2, the flow curves showed a shear stress overshoot after the onset of shear where shear rate is low $\left(0-50 \mathrm{~s}^{-1}\right)$, which was more pronounced after $28 \mathrm{~d}$ of storage. According to Barnes (1997), thixotropic materials that have been at rest for some time show viscoelastic behavior, so the immediate response is elastic; then, depending on the conditions, a thixotropic response will be seen as an overshoot in the flow curves. Hence, this phenomenon is composed of 2 steps: first the resistance to shear force of the gel network (Riscardo et al., 2003); and then, the breakdown after a critical shear rate values. The largest overshoot was observed in the sample TC (control).

As observed in Figure 2, the samples presented pseudoplastic behavior. It was found that the curve TC (control) showed different behavior when compared with the other curves, presenting higher shear stress values, whereas the samples added with antioxidants exhibited lower values whose behavior was similar among them.

A thixotropic behavior can be estimated using the difference between the areas under the curves of shear rate versus shear stress (growing rate 1 and 2; Steffe, 1996; Sato and Cunha, 2007), once the energy required for disrupting the gel structure is proportional to the area of the hysteresis (Schramm, 1998). This measure can be used as a qualitative comparison between treatments, as shown in Figure 3. According to Figure 3, thixotropy of TC (control) was extremely higher than the other samples. No significant difference was observed among the samples added with antioxidants. This indicates that antioxidants incorporated to petit

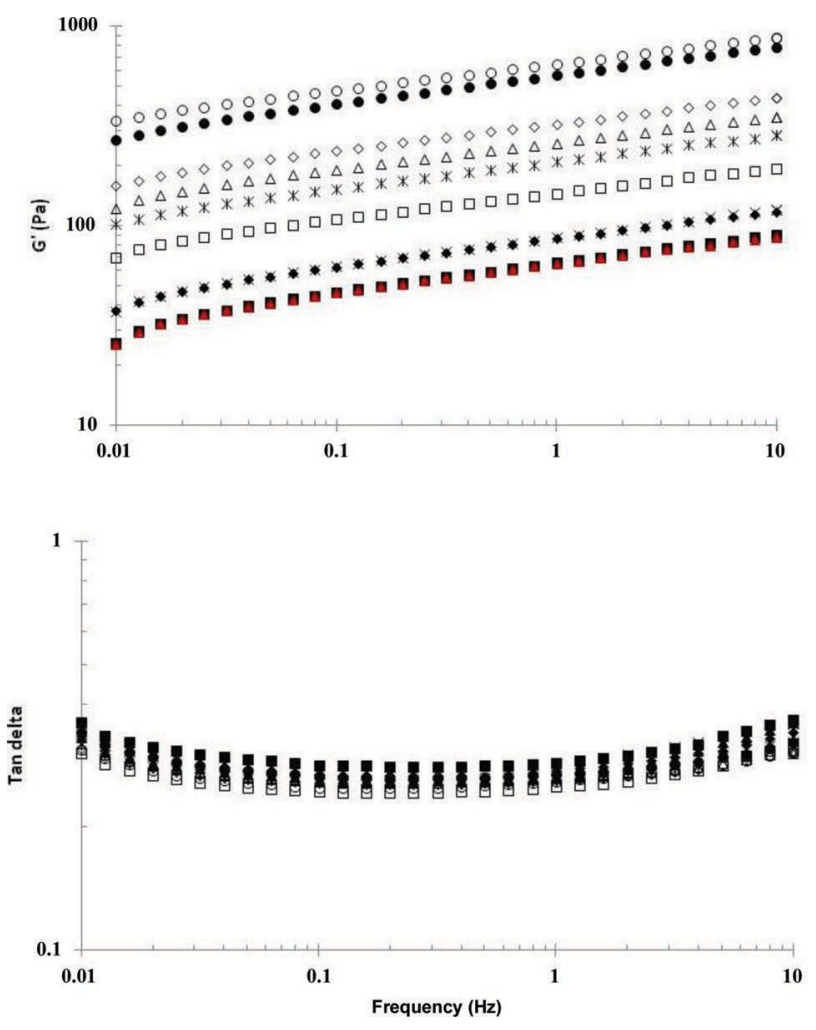

(A)

(B)

Figure 1. Mechanical spectrum of the probiotic petit suisse formulations: control $(\bullet)$, ascorbic acid $(\bullet)$, glucose oxidase $(\boldsymbol{\square})$, cysteine $(\boldsymbol{\Lambda})$, and jabuticaba extract $(*)$. Storage modulus $\left(\mathrm{G}^{\prime} ; \mathrm{A}\right)$ and loss tangent $\left(\tan \delta=\mathrm{G}^{\prime \prime} / \mathrm{G}^{\prime} ; \mathrm{B}\right)$ for $1 \mathrm{~d}$ (solid symbols) and $28 \mathrm{~d}$ (open symbols) of refrigerated storage. Color version available online. 


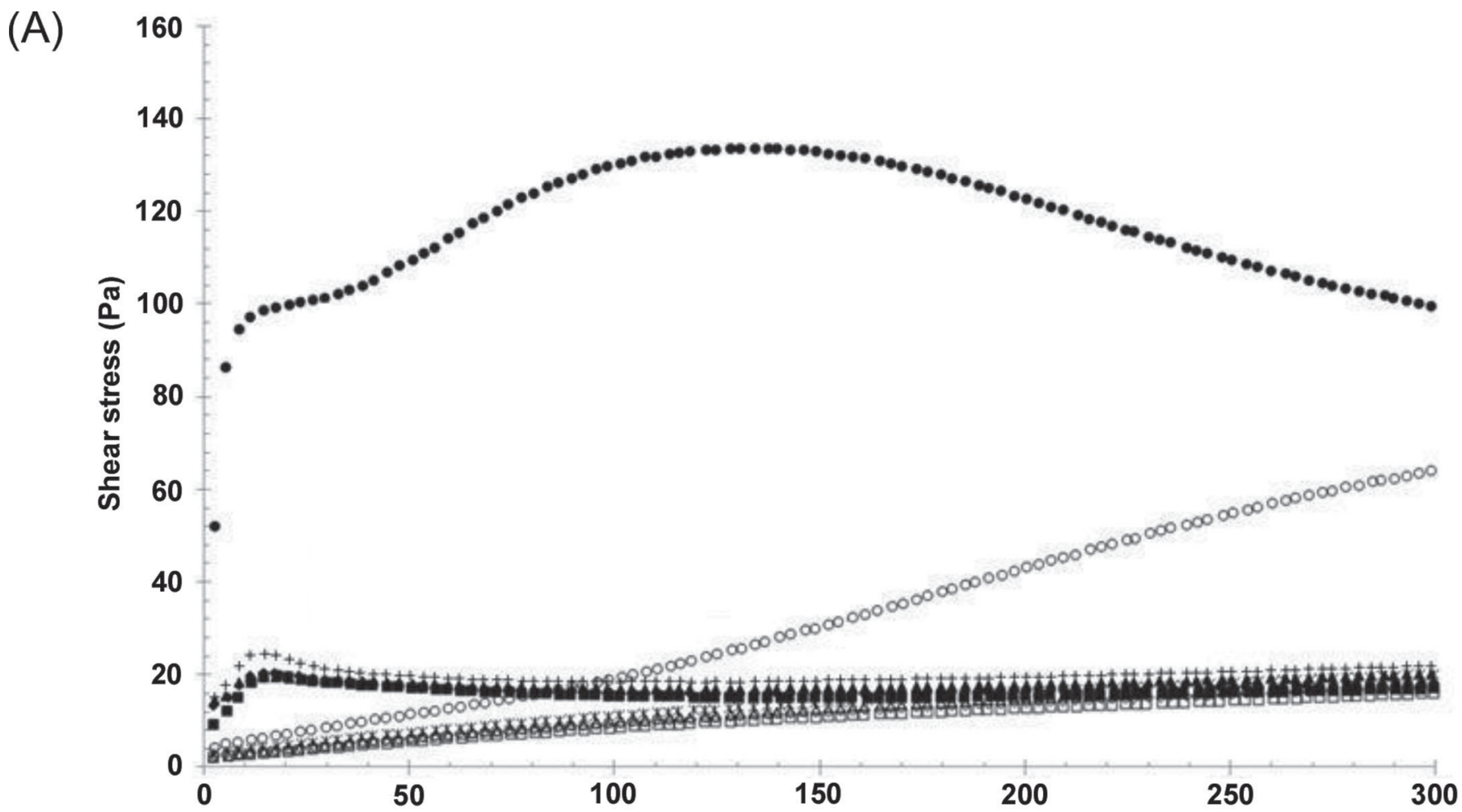

(B)

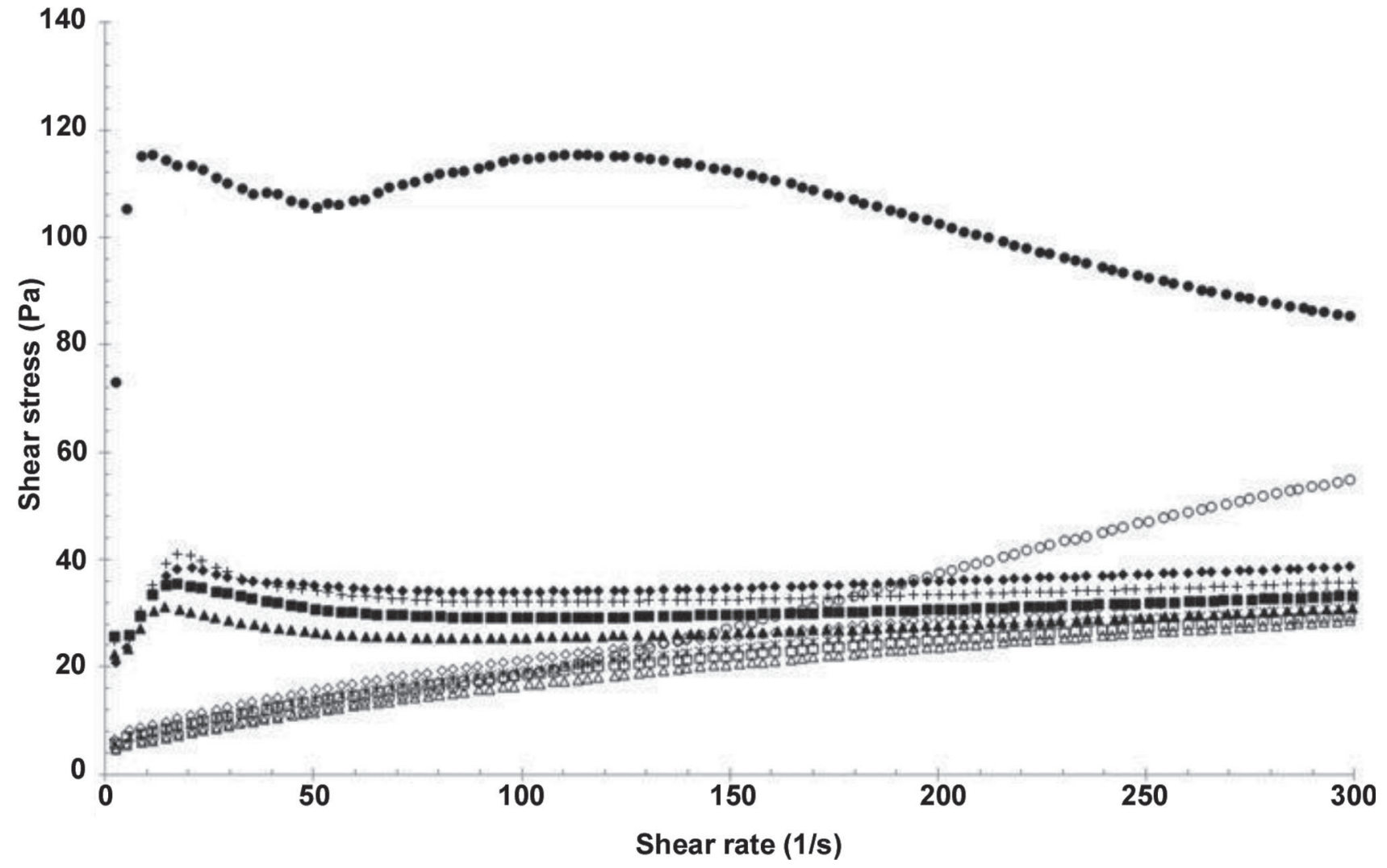

Figure 2. Flow curves of the probiotic petit suisse formulations: control $(\bullet)$, ascorbic acid $(\bullet)$, glucose oxidase $(\boldsymbol{\square})$, cysteine $(\boldsymbol{\Delta})$, and jabuticaba extract (*). Increasing 1 (solid symbol) and increasing 2 (open symbol) at $1 \mathrm{~d}(\mathrm{~A})$ and $28 \mathrm{~d}(\mathrm{~B})$ of refrigerated storage. 
Table 2. Rheological parameters estimated by Herschel-Bulkley model for flow curves of the probiotic petit suisse cheese ${ }^{1}$

\begin{tabular}{lllllll}
\hline Item & Day & TC & TAA & TGO & TCI & TJE \\
\hline$\sigma_{0}(\mathrm{~Pa})$ & 1 & $5.04^{\mathrm{a}, \mathrm{A}}$ & $1.02^{\mathrm{b}, \mathrm{B}}$ & $0.76^{\mathrm{b}, \mathrm{B}}$ & $1.14^{\mathrm{b}, \mathrm{B}}$ & $1.43^{\mathrm{b}, \mathrm{B}}$ \\
& 28 & $4.93^{\mathrm{a}, \mathrm{A}}$ & $2.84^{\mathrm{b}, \mathrm{A}}$ & $2.09^{\mathrm{b}, \mathrm{A}}$ & $2.98^{\mathrm{b}, \mathrm{A}}$ & $2.23^{\mathrm{b}, \mathrm{A}}$ \\
$n$ & 1 & $1.24^{\mathrm{a}, \mathrm{A}}$ & $0.63^{\mathrm{b}, \mathrm{A}}$ & $0.64^{\mathrm{b}, \mathrm{A}}$ & $0.64^{\mathrm{b}, \mathrm{A}}$ & $0.61^{\mathrm{b}, \mathrm{A}}$ \\
& 28 & $1.22^{\mathrm{a}, \mathrm{B}}$ & $0.52^{\mathrm{b}, \mathrm{B}}$ & $0.57^{\mathrm{b}, \mathrm{B}}$ & $0.52^{\mathrm{b}, \mathrm{B}}$ & $0.49^{\mathrm{b}, \mathrm{B}}$ \\
& 1 & $0.05^{\mathrm{b}, \mathrm{A}}$ & $0.47^{\mathrm{a}, \mathrm{B}}$ & $0.47^{\mathrm{a}, \mathrm{B}}$ & $0.41^{\mathrm{a}, \mathrm{B}}$ & $0.61^{\mathrm{a}, \mathrm{B}}$ \\
& 28 & $0.05^{\mathrm{c}, \mathrm{A}}$ & $1.47^{\mathrm{ab}, \mathrm{A}}$ & $1.02^{\mathrm{b}, \mathrm{A}}$ & $1.41^{\mathrm{n}, \mathrm{A}}$ & $1.73^{\mathrm{a}, \mathrm{A}}$ \\
\hline
\end{tabular}

${ }^{a-c}$ Data that share a common lowercase letter in the same row do not differ significantly from one another between different samples for the same day of storage $(P<0.05)$.

${ }_{\mathrm{A}, \mathrm{B}}$ Data that share a common uppercase letter in the same column do not differ significantly considering different days of storage for the same sample $(P<0.05)$.

${ }^{1} \mathrm{TC}$, TAA, TGO, TCI, TJE = probiotic petit suisse cheese without antioxidant (control), with ascorbic acid, glucose oxidase, cysteine, and jabuticaba extract, respectively. $\sigma_{0}$ is the yield stress, $n$ is the flow behavior index, and $k$ is the consistency index.

suisse had a protective effect on the typical thixotropic behavior of the Quark gel.

The increasing shear rate curves were modeled mathematically using the Herschel-Bulkley equation (equation 1), and the results are shown in Table 2. The coefficient of determination $\left(\mathrm{R}^{2}\right)$ varies from 0.989 to 0.997. The sample TC (control) showed dilatant behavior with $\mathrm{n}$ values greater than 1 . On the other hand, the addition of antioxidant has changed this behavior to pseudoplastic, with $\mathrm{n}$ values around 0.63 at $\mathrm{d} 1$ and 0.52 at $28 \mathrm{~d}$ of storage. This behavior may be related to the new chemical interactions formed by the antioxidant compounds and Quark gel network, the small quantity of water incorporated, or even the shearing during antioxidant addiction also may influence rheological behavior.

The residual stress $\left(\sigma_{0}\right)$ values decreased with addition of the antioxidant agent, regardless of storage time. Although the storage time did not affect the $\sigma_{0}$ value of the control sample (TC), higher $\sigma_{0}$ values were observed for the other samples containing antioxidants, whereas $k$ values increased with the addition of antioxidant, independent of the storage time. In addition, despite the storage time did not affect the $k$ values of the probiotic cheeses without the addition of antioxidants (TC), higher $k$ values were observed for the cheeses containing antioxidant agents. This indicates that although the samples containing antioxidants are less viscous and consistent, an increase in viscosity was observed during storage whereas the control remained stable over $28 \mathrm{~d}$.

According to Table 3, at d 1 of storage, the sample TC (control) showed the highest apparent viscosity at different shear rates as compared with other treatments. However, after 28 d of storage, no differences in viscosity values were observed. The sample TJE showed the greatest $\sigma_{0}$ value and apparent viscosity when compared with the formulations containing anti-

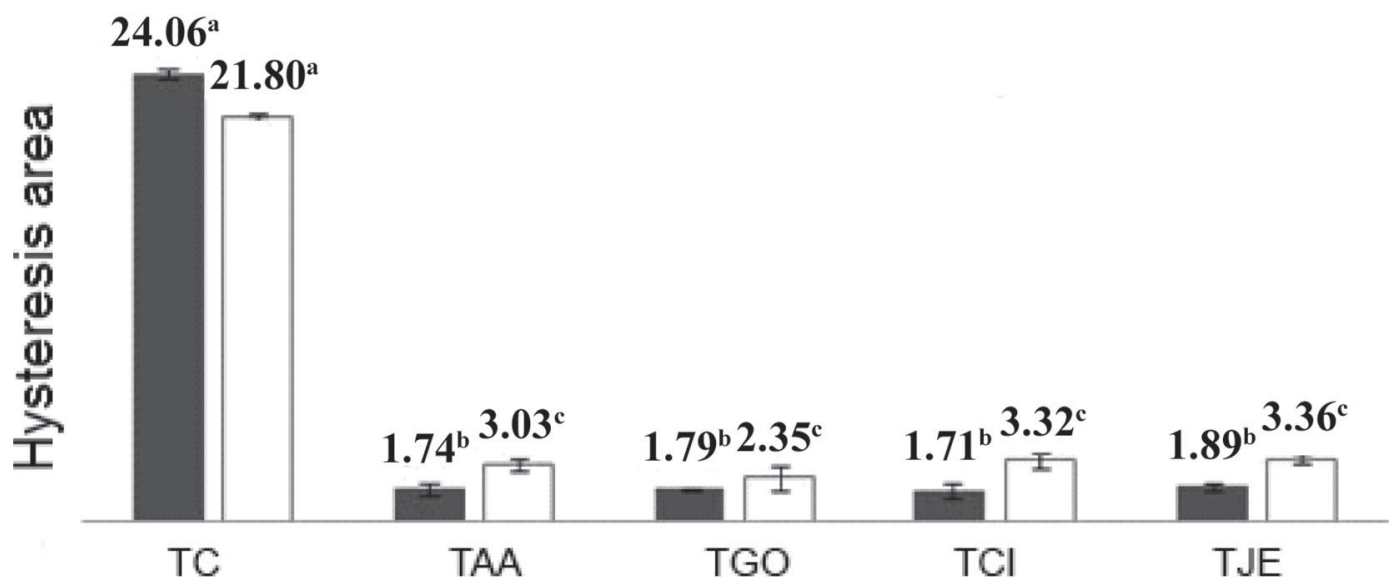

Figure 3. Hysteresis loop area $\left(\mathrm{Pa} \cdot \mathrm{s}^{-1}\right)$ of the probiotic petit suisse formulations: control (TC), ascorbic acid (TAA), glucose oxidase (TGO), cysteine (TCI), and jabuticaba extract (TJE) at $1 \mathrm{~d}(\mathbf{\square})$ and $28 \mathrm{~d}(\square)$ of refrigerated storage. Bars with the same letter (a, b, c) do not differ significantly from one another with respect to sample formulations and day of storage $(P<0.05)$. Error bars represent standard deviations. 
Table 3. Apparent viscosity $(\mathrm{Pa} \cdot \mathrm{s})$ of the probiotic petit suisse cheese ${ }^{1}$

\begin{tabular}{lllllll}
\hline Shear rate & Day & TC & TAA & TGO & TCI & TJE \\
\hline $10 \mathrm{~s}^{-1}$ & 1 & $0.57^{\mathrm{a}, \mathrm{A}}$ & $0.29^{\mathrm{b}, \mathrm{B}}$ & $0.27^{\mathrm{b}, \mathrm{B}}$ & $0.28^{\mathrm{b}, \mathrm{B}}$ & $0.36^{\mathrm{ab}, \mathrm{A}}$ \\
& 28 & $0.54^{\mathrm{a}, \mathrm{A}}$ & $0.72^{\mathrm{a}, \mathrm{A}}$ & $0.55^{\mathrm{a}, \mathrm{A}}$ & $0.71^{\mathrm{a}, \mathrm{A}}$ & $0.71^{\mathrm{a}, \mathrm{A}}$ \\
$50 \mathrm{~s}^{-1}$ & 1 & $0.24^{\mathrm{a}, \mathrm{A}}$ & $0.12^{\mathrm{b}, \mathrm{B}}$ & $0.13^{\mathrm{b}, \mathrm{B}}$ & $0.12^{\mathrm{b}, \mathrm{B}}$ & $0.16^{\mathrm{b}, \mathrm{B}}$ \\
& 28 & $0.22^{\mathrm{a}, \mathrm{A}}$ & $0.27^{\mathrm{a}, \mathrm{A}}$ & $0.22^{\mathrm{a}, \mathrm{A}}$ & $0.27^{\mathrm{a}, \mathrm{A}}$ & $0.28^{\mathrm{a}, \mathrm{A}}$ \\
$100 \mathrm{~s}^{-1}$ & 1 & $0.20^{\mathrm{a}, \mathrm{A}}$ & $0.09^{\mathrm{b}, \mathrm{B}}$ & $0.10^{\mathrm{b}, \mathrm{B}}$ & $0.09^{\mathrm{b}, \mathrm{B}}$ & $0.11^{\mathrm{b}, \mathrm{B}}$ \\
& 28 & $0.18^{\mathrm{a}, \mathrm{A}}$ & $0.19^{\mathrm{a}, \mathrm{A}}$ & $0.16^{\mathrm{a}, \mathrm{A}}$ & $0.18^{\mathrm{a}, \mathrm{A}}$ & $0.19^{\mathrm{a}, \mathrm{A}}$ \\
\hline
\end{tabular}

$\overline{\mathrm{a}}^{\mathrm{b}}$ Data that share a common lowercase letter in the same row do not differ significantly from one another between different samples for the same day of storage $(P<0.05)$.

${ }^{\mathrm{A}, \mathrm{B}}$ Data that share a common uppercase letter in the same column do not differ significantly considering different days of storage for the same sample $(P<0.05)$.

${ }^{1} \mathrm{TC}, \mathrm{TAA}, \mathrm{TGO}, \mathrm{TCI}, \mathrm{TJE}=$ probiotic petit suisse cheese without antioxidant (control), with ascorbic acid, glucose oxidase, cysteine, and jabuticaba extract, respectively.

oxidants, which indicates a greater similarity with the control (TC).

\section{Sensory Analysis}

The results of the consumer test of probiotic petit suisse are shown in Table 4. In general, the commercial sample $(\mathbf{C O M})$ showed a better performance for all attributes $(P<0.05)$ that were situated between 6 (like slightly) and 8 (like very much), which can be evidenced by the sensory scores of 7.43 (appearance), 7.85 (aroma), 7.92 (flavor), 7.97 (texture), and 7.90 (overall acceptance). With respect to petit suisse containing antioxidants, regardless of the type of antioxidant added, negative scores were observed for all attributes. Although the petit suisse cheese added with jabuticaba extract (TJE) received the best scores for the sensory attribute texture (4.72), these values cannot be considered adequate. On the reverse, TGO presented superior performance for all sensory attributes, with scores of $6.12,6.57,5.50$, and 5.90 for appearance, aroma, flavor, and overall acceptance, respectively, For these attributes, TJE had a regular performance, which varied according to the sensory attribute analyzed, with intermediate values for aroma (6.25) and lower values for appearance, flavor, and overall acceptance, 5.95, 4.68, and 5.02, respectively. The good performance of the commercial sample may be related to a definitive formulation, in which it was submitted to previous tests before commercialization, whereas for TGO, the good performance may be due to the increased production of diacetyl compounds and acetaldehyde, which are intrinsic to the yogurt and have been shown in previous studies (Cruz et al., 2012, 2013b), whereas possible generation of off flavor may be related to the presence of other antioxidants in yogurt matrix, and its interaction with the lactic acid and probiotic cultures. The results indicate the need for prototyping the samples with respect to the commercially available samples (Cruz et al., 2010). In this particular case, the addition of a commercial strawberry pulp can minimize this problem, as these products contain sucrose, which gives a sweet taste.

Controversially, regarding the purchase intention, 93\% of assessors would buy the commercial sample, and $83 \%$ would buy the sample containing TJE, which showed a good consumer interest. It is important to mention the repeated purchase will occur if the product fulfills consumers' expectations before the purchase, which will depend on good product quality.

Figure 4 shows the sensory map obtained by MFA for analysis of the projected map. In 2 dimensions, the variance of experimental data was $53.84 \%$, being 33.60 and $20.24 \%$, respectively, for the first and second di-

Table 4. Sensory acceptance of probiotic and commercial petit suisse cheese ${ }^{1}$

\begin{tabular}{|c|c|c|c|c|c|c|}
\hline Item & $\mathrm{TC}$ & TAA & TGO & TCI & TJE & Commercial \\
\hline Appearance & $6.08^{\mathrm{b}}$ & $5.98^{\mathrm{b}}$ & $6.12^{\mathrm{b}}$ & $6.12^{\mathrm{b}}$ & $5.95^{\mathrm{b}}$ & $7.43^{\mathrm{a}}$ \\
\hline Aroma & $6.45^{\mathrm{b}}$ & $5.80^{\mathrm{bc}}$ & $6.57^{\mathrm{b}}$ & $5.58^{c}$ & $6.25^{\mathrm{bc}}$ & $7.85^{\mathrm{a}}$ \\
\hline Flavor & $5.57^{\mathrm{bc}}$ & $5.32^{\mathrm{bcd}}$ & $5.90^{\mathrm{b}}$ & $4.37^{\mathrm{d}}$ & $4.68^{\mathrm{cd}}$ & $7.92^{\mathrm{a}}$ \\
\hline Texture & $4.42^{\mathrm{b}}$ & $4.67^{\mathrm{b}}$ & $4.55^{\mathrm{b}}$ & $4.50^{\mathrm{b}}$ & $4.72^{\mathrm{b}}$ & $7.97^{\mathrm{a}}$ \\
\hline Overall acceptance & $5.48^{\mathrm{b}}$ & $5.27^{\mathrm{bc}}$ & $5.50^{\mathrm{b}}$ & $4.53^{\mathrm{c}}$ & $5.02^{\mathrm{bc}}$ & $7.90^{\mathrm{a}}$ \\
\hline
\end{tabular}

${ }^{\mathrm{a}-\mathrm{d}}$ Mean values in the same row not followed by the same letter are significantly different $(P<0.05)$.

${ }^{1} \mathrm{TC}, \mathrm{TAA}, \mathrm{TGO}, \mathrm{TCI}, \mathrm{TJE}=$ probiotic petit suisse cheese without antioxidant (control), with ascorbic acid, glucose oxidase, cysteine, and jabuticaba extract, respectively. Commercial = commercial petit suisse cheese without probiotic bacteria. Mean data from 60 consumers and based on a 9-point hedonic scale $(1=$ dislike extremely; $5=$ neither like nor dislike; $9=$ like extremely). 
mensions. Because projective mapping was performed with consumers, who present different perceptions about the products, these findings can be intrinsically involved and constitute a limitation of the methodology. However, it was observed that the samples were clearly distinguished by the consumers according to their characteristics along horizontal and vertical axes, suggesting that the assessors used all available space on the paper sheet to put the samples (data not shown). The control sample (TC) and the samples containing ascorbic acid, cysteine, and glucose oxidase (TAA, TCI, TGO), respectively, were characterized by the attributes yogurt, presence of spots, sandy, strawberry flavor, aerated, sour taste, milky taste, and acid aroma, whereas the sample containing jabuticaba extract showed an intermediate behavior and was not associated with any specific attribute. On the other hand, the commercial sample (COM) was characterized by the descriptors pink, purple, and viscous, which can be considered drivers of liking, once they are associated with a sample with high overall acceptance.

The dendrogram generated by the application of HCA (Figure 5) showed the existence of 3 groups: group I (COM and TJE), group II (TGO), and group III (TCI, TAA, and TC). Samples obtained using biotechnological alternatives and clean processes such as supercritical extraction (glucose oxidase and jabuticaba extract) are opposed to samples containing chemical compounds, suggesting the differences in the perception of consumers for these samples. Interestingly, as reported below, the samples containing glucose oxidase and jabuticaba extract belong to the same group even with different scores in overall liking, which is directly related to citation frequency of purple color descriptor that was only perceived by consumers in these 2 samples.

Table 5 shows the vocabulary generated during the performance of the projected map. In total, 12 descriptors were listed as follows: 4 for appearance (pink, purple, aerated, and spots), 1 for flavor (acid aroma), 5 for taste (sweet, strawberry, yogurt, acidic, and dairy), and 2 for texture (viscous and sandy). The highest citation frequencies were observed for the descriptors pink color, viscous, and sandy with 58, 55, and 32 citations, whereas the attributes dairy taste, acid aroma, and yogurt taste had the lowest citation frequencies of 9,8 , and 6 , respectively. The results suggest that consumers' perceptions with regard to the sensory attributes of petit suisse are multidimensional and may be due to the flavor-aroma interactions and texture at the time of tasting. Regarding the type of sample, COM was associated with a higher citation of the attributes purple and viscous color (11 and 13, respectively). Samples
(A)

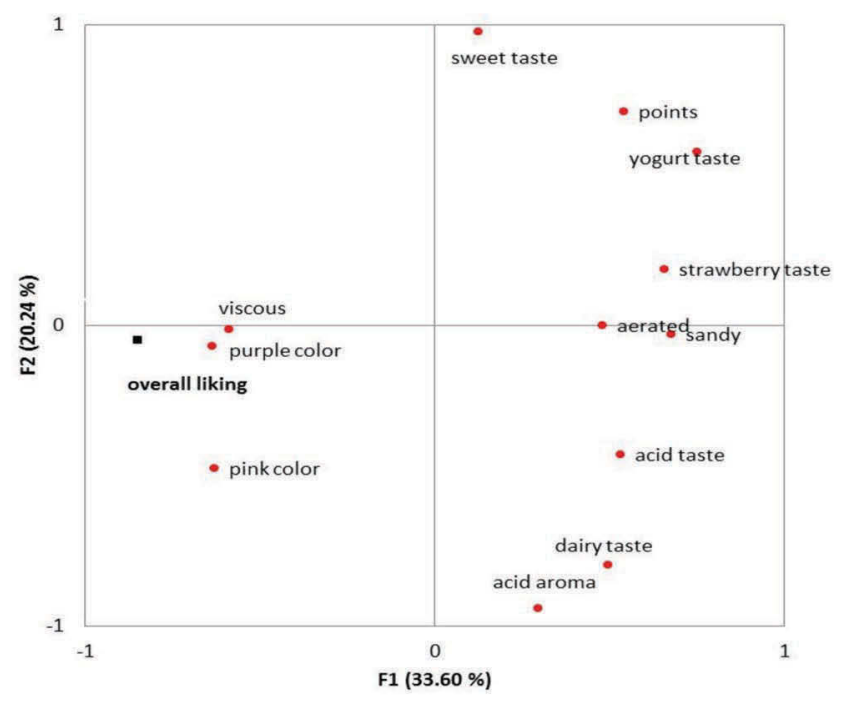

(B)

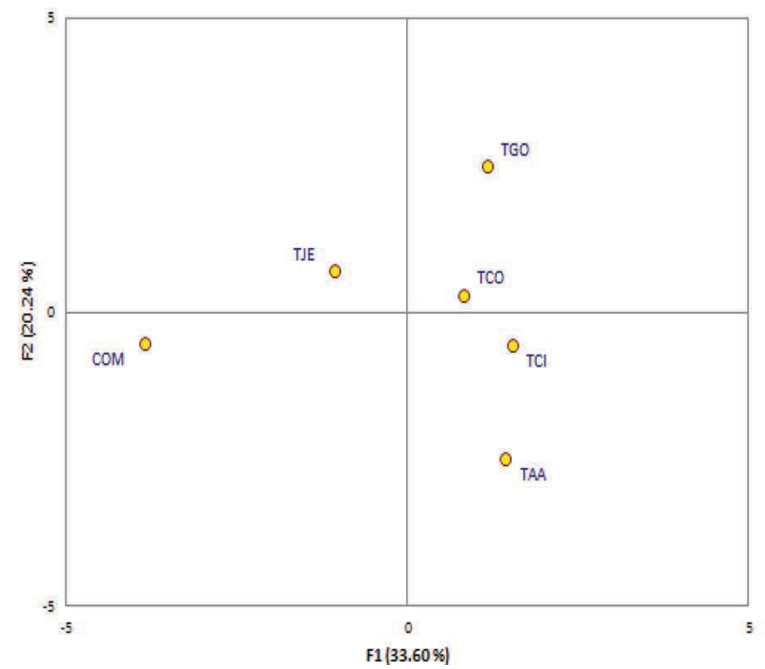

Figure 4. Representation of the sensory descriptors (A) and samples (B) from multiple factor analysis of projective mapping of the commercial sample (COM) and probiotic petit suisse formulations control (TC), ascorbic acid (TAA), glucose oxidase (TGO), cysteine (TCI), and jabuticaba extract (TJE) for the first 2 dimensions. Color version available online.

containing antioxidants had a variable frequency; in particular, the attribute purple color was only perceived in the COM and TJE sample, which contributed to its similarity in the dendrogram after applying HCA.

Although the projective map is based on a holistic and global awareness of similarities and differences of the products (Varela and Ares, 2012), the generation of a preliminary vocabulary that characterized the set of samples was observed, which can be the initial step to optimize the petit suisse formulations. In this context, the use of a trained panel using quantitative descriptive analysis is recommended. 
Table 5. Vocabulary of projective mapping ${ }^{1}$

\begin{tabular}{|c|c|c|c|c|c|c|}
\hline Item & $\mathrm{TC}$ & TAA & TGO & TCI & TJE & Commercial \\
\hline \multirow{2}{*}{ Appearance } & Aerated (5) & Aerated (2) & Aerated (2) & Aerated (2) & - & Aerated (1) \\
\hline & - & Points (1) & Points (2) & Points (2) & - & - \\
\hline Aroma & Acid (1) & Acid (3) & - & Acid (2) & Acid (1) & Acid (1) \\
\hline \multirow[t]{2}{*}{ Taste } & Sweet (5) & Sweet (3) & Sweet (7) & Sweet (4) & Sweet (5) & Sweet (4) \\
\hline & Strawberry (4) & Strawberry (4) & Strawberry (6) & Strawberry (4) & Strawberry (0) & Strawberry (2) \\
\hline \multirow[t]{2}{*}{ Texture } & Sandy (7) & Sandy (6) & Sandy (4) & Sandy (7) & Sandy (8) & \\
\hline & Viscous (4) & Viscous (4) & Viscous (4) & Viscous (3) & Viscous (3) & Viscous (13) \\
\hline
\end{tabular}

${ }^{1}$ TC, TAA, TGO, TCI, TJE = probiotic petit suisse cheese without antioxidant (control), with ascorbic acid, glucose oxidase, cysteine, and jabuticaba extract, respectively. Commercial $=$ commercial petit suisse cheese without probiotic bacteria. The number of citations of the sensory attribute is in parentheses.

\section{CONCLUSIONS}

The addition of antioxidants in probiotic petit suisse processing did not affect the physicochemical composition of the probiotic petit suisse, whereas the rheological characteristics of the product were altered, showing a pseudoplastic behavior. However, higher hysteresis area also was obtained for control petit suisse cheese, which suggest that antioxidants incorporated with petit suisse had a protective effect on the typical thixotropic behavior of the quark gel. From a sensory standpoint, the addition of antioxidants resulted in lower scores for all sensory attributes evaluated for COM, suggesting the need for optimization of the formulations. However,

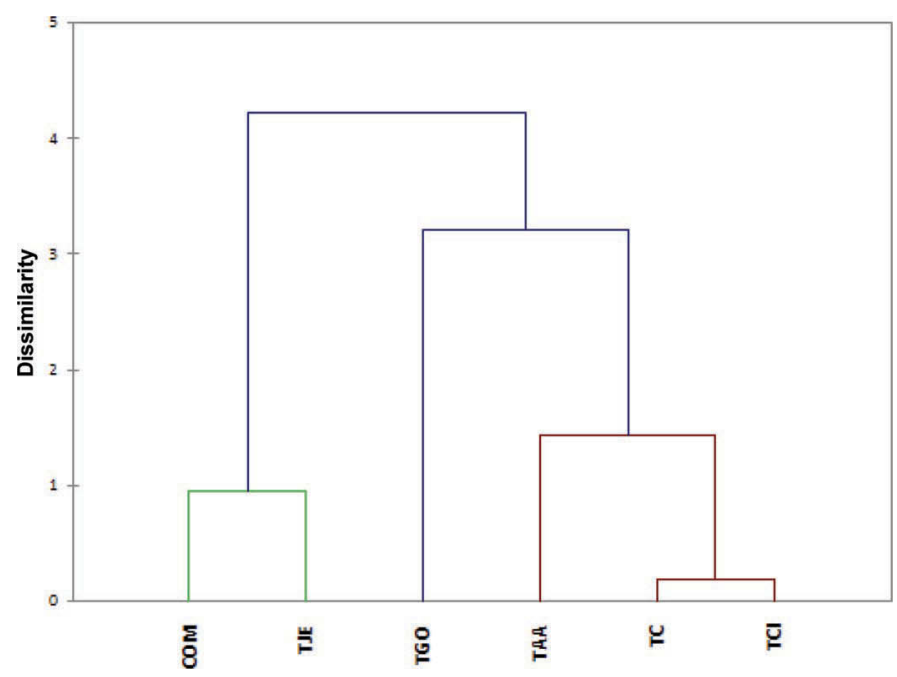

Figure 5. Dendrogram obtained from hierarchical cluster analysis of projective mapping. Color version available online. Commercial sample (COM), jabuticaba extract (TJE), glucose oxidase (TGO), ascorbic acid (TAA), control (TC), and cysteine (TCI). Color version available online. a projective sensory map indicated that perception of the samples by the consumers is multidimensional with regard to the sensory attributes; in this case, the sample containing jabuticaba extract was similar to COM, being characterized by sensory descriptors related to appearance (pink and purple) and texture (viscous).

\section{REFERENCES}

AOAC International. 2006. Official Methods of Analysis. 18th ed. AOAC Int., Washington, DC.

Barnes, H. A. 1997. Thixotropy: A review. J. Non-Newt. Fluid Mech. 70:1-33.

Batista, A. L. D., R. Silva, L. P. Cappato, C. N. Almada, R. K. A. Garcia, M. C. Silva, R. S. L. Raices, D. B. Arellano, A. S. Sant'Ana, C. A. Conte Junior, M. Q. Freitas, and A. G. Cruz. 2015. Quality parameters of probiotic yogurt added to glucose oxidase compared to commercial products through microbiological, physical-chemical and metabolic activity analyses. Food Res. Int. 77:627-635.

Bligh, E. G., and W. J. Dyer. 1959. A rapid method of total lipid extraction and purification. Can. J. Biochem. Physiol. 37:911-917.

Cruz, A. G., F. C. A. Buriti, C. H. B. Souza, J. A. F. Faria, and S. M. I. Saad. 2009. Probiotic cheese: Health benefits, technological and stability aspects. Trends Food Sci. Technol. 20:344-354.

Cruz, A. G., R. S. Cadena, J. A. F. Faria, C. A. F. Oliveira, R. N. Cavalcanti, E. Bona, H. M. A. Bolini, and M. A. A. P. Silva. 2011. Consumer acceptability and purchase intent of probiotic yoghurt with added glucose oxidase using sensometrics, artificial neural networks and logistic regression. Int. J. Dairy Technol. 64:549-556.

Cruz, A. G., R. S. Cadena, E. H. M. Walter, A. M. Mortazavian, D Granato, J. A. F. Faria, and H. M. A. Bolini. 2010. Relevance for prebiotic, probiotic, and synbiotic product development. Comp. Rev. Food Sci. Saf. 9:358-373.

Cruz, A. G., W. F. Castro, J. A. F. Faria, H. M. A. Bolini, R. M. S. Celeghini, R. S. L. Raices, C. A. F. Oliveira, M. Q. Freitas, C. A. Conte Júnior, and E. T. Mársico. 2013a. Stability of probiotic yogurt added with glucose oxidase in plastic materials with different permeability oxygen rates during the refrigerated storage. Food Res. Int. 51:723-728.

Cruz, A. G., W. F. Castro, J. A. F. Faria, P. C. B. Lollo, J. AmayaFarfán, M. Q. Freitas, D. Rodrigues, C. A. F. Oliveira, and H. T. Godoy. 2012. Probiotic yogurts manufactured with increased glucose oxidase levels: Postacidification, proteolytic patterns, survival of probiotic microorganisms, production of organic acid and aroma compounds. J. Dairy Sci. 95:2261-2269. 
Cruz, A. G., R. N. Cavalcanti, L. M. R. Guerreiro, A. S. Sant'Ana, L. C. Nogueira, C. A. F. Oliveira, R. Deliza, R. L. Cunha, J. A. F. Faria, and H. M. A. Bolini. 2013b. Developing a prebiotic yogurt: Rheological, physico-chemical and microbiological aspects and adequacy of survival analysis methodology. J. Food Eng. 114:323-330.

Dave, R. I., and N. P. Shah. 1997a. Effect of cysteine on the viability of yoghurt and probiotic bacteria in yoghurts made with commercial starter cultures. Int. Dairy J. 7:537-545.

Dave, R. I., and N. P. Shah. 1997b. Effectiveness of ascorbic acid as an oxygen scavenger in improving viability of probiotic bacteria in yoghurts made with commercial starter cultures. Int. Dairy J. 7:435-443.

El Samh, M. M. A., A. D. Sherein, and H. H. Essam. 2013. Properties and antioxidant activity of probiotic yoghurt flavored with black carrot, pumpkin and strawberry. Int. J. Dairy Sci. 8:48-57.

Esmerino, E. A., A. G. Cruz, E. P. R. Pereira, J. B. Rodrigues, J. A. F. Faria, and H. M. A. Bolini. 2013. The influence of sweeteners in probiotic Petit Suisse cheese in concentrations equivalent to that of sucrose. J. Dairy Sci. 96:5512-5521.

Fox, P. F., T. P. Guinee, T. M. Cogan, and P. H. L. Mcsweeney. 2000. Biochemistry of cheese ripening. Pages 236-281 in Fundamentals of Cheese Science. P. F. Fox, T. P. Guinee, T. M. Cogan, P. L. H. McSweeney, ed. Aspen Publishers, Frederick, MD.

Fritzen-Freire, C. B., C. M. O. Müller, J. B. Laurindo, R. D. M. C. Amboni, and E. S. Prudêncio. 2010. The effect of direct acidification on the microbiological, physicochemical and sensory properties of probiotic Minas Frescal cheese. Int. J. Dairy Technol. 63:561-568.

Fröhlich-Wyder, M. T., D. Guggisberg, and D. Wechsler. 2009. Influence of low calcium and low $\mathrm{pH}$ on melting characteristics of model Raclette cheese. Dairy Sci. Technol. 89:463-483.

Gaze, L. V., B. R. Oliveira, L. L. Ferrao, D. Granato, R. N. Cavalcanti, C. A. Conte Júnior, A. G. Cruz, and M. Q. Freitas. 2015. Preference mapping of dulce de leche commercialized in Brazilian markets. J. Dairy Sci. 98:1443-1454.

Granato, D., G. F. Branco, A. G. Cruz, J. A. F. Faria, and N. P. Shah. 2010. Probiotic dairy products as functional foods. Comp. Rev. Food Sci. Saf. 9:455-470.

Jervis, M. G., and M. A. Drake. 2014. The use of qualitative research methods in quantitative science: A review. J. Sens. Stud. 29:234247.

Karimi, R., S. Sohrabvandi, and A. M. Mortazavian. 2012. Sensory characteristics of probiotic cheese. Comp. Rev. Food Sci. Saf. 11:437-452.

Kim, Y. K., L. Jombart, D. Valentin, and K. O. Kim. 2013. A crosscultural study using Napping ${ }^{\circledR}$ : Do Korean and French consumers perceive various green tea products differently? Food Res. Int. 53:534-542.

Kuhn, K. R., F. G. D. Silva, F. M. Netto, and R. L. Cunha. 2014. Assessing the potential of flaxseed protein as an emulsifier combined with whey protein isolate. Food Res. Int. 59:89-97.

Lucey, J. A., M. E. Johnson, and D. S. Horne. 2003. Perspective on the basis of the rheology and texture properties of cheese. J. Dairy Sci. 86:2725-2743.

Marcano, J., G. Ares, and S. Fiszman. 2014. Comparison of partial and global projective mapping with consumers: A case study with satiating cheese pies. Food Res. Int. 67:323-330.

Michael, M., R. K. Phebus, and K. A. Schmidt. 2010. Impact of a plant extract on the viability of Lactobacillus delbrueckii ssp. bul- garicus and Streptococcus thermophilus in nonfat yogurt. Int. Dairy J. 20:665-672.

Morais, E. C., A. R. Morais, A. G. Cruz, and H. M. A. Bolini. 2014. Development of chocolate dairy dessert with addition of prebiotics and replacement of sucrose with different high-intensity sweeteners. J. Dairy Sci. 97:2600-2609.

O'Callaghan, D. J., and T. P. Guinee. 2004. Rheology and texture of cheese. Pages 511-540 in Cheese: Chemistry, Physics and Microbiology. 3rd ed. P. F. Fox, P. L. H. McSweeney, T. M. C. Cogan, and T. P. Guinee, ed. Academic Press, New York, NY

Paixão, J. A., J. B. Rodrigues, E. A. Esmerino, A. G. Cruz, and H. M. A. Bolini. 2014. Influence of temperature and fat content on ideal sucrose concentration, sweetening power, and sweetness equivalence of different sweeteners in chocolate milk beverage. J. Dairy Sci. 97:7344-7353.

Perrechil, F. A., R. C. Santana, L. H. Fasolin, C. A. S. Silva, and R. L. Cunha. 2010. Rheological and structural evaluations of commercial Italian salad dressings. Ciênc. Tecnol. Aliment. 30:477-482.

Ramírez-Santiago, C., C. Lobato-Calleros, H. Espinosa-Andrews, and E. J. Vernon-Carter. 2012. Viscoelastic properties and overall sensory acceptability of reduced-fat Petit-Suisse cheese made by replacing milk fat with complex coacervate. Dairy Sci. Technol. 92:383-398.

Riscardo, M. A., J. M. Franco, and C. Gallegos. 2003. Influence of composition of emulsifier blends on the rheological properties of salad dressing-type emulsions. Food Sci. Technol. Int. 9:53-63.

Santos, B. A., M. A. R. Pollonio, A. G. Cruz, V. C. Messias, R. A. Monteiro, T. L. C. Oliveira, J. A. F. Faria, M. Q. Freitas, and H. M. A. Bolini. 2013. Ultra-flash profile and projective mapping for describing sensory attributes of prebiotic mortadellas. Food Res. Int. 54:1705-1711.

Sato, A. C. K., and R. L. Cunha. 2007. Influence of temperature on the rheological behavior of jaboticaba pulp. Ciênc. Tecn. Aliment. $27: 890-896$.

Schramm, G. 1998. Rheology: Fundamentals and Practice. Osrodek Wydawnictw Nawkowygh Pan Poznán [in Polish].

Shah, N. P., W. K. Ding, M. J. Fallourd, and G. Leyer. 2010. Improving the stability of probiotic bacteria in model fruit juices using vitamins and antioxidants. J. Food Sci. 75:M@78-282.

Silva, V. M., A. C. K. Sato, G. Barbosa, G. Dacanal, H. J. CiroVelásquez, and R. L. Cunha. 2010. The effect of homogenisation on the stability of pineapple pulp. Int. J. Food Sci. Technol. 45:2127-2133.

Steffe, J. F. 1996. Rheological Methods in Food Process Engineering. 2nd ed. Freeman Press, East Lansing, MI.

Tripathi, M. K., and S. K. Giri. 2014. Probiotic functional foods: Survival of probiotics during processing and storage. J. Funct. Foods 9:225-241.

Van den Ende, W., D. Peshev, and L. Gara. 2011. Disease prevention by natural antioxidants and prebiotics acting as ROS scavengers in the gastrointestinal tract. Trends Food Sci. Technol. 22:689-697.

Varela, P., and G. Ares. 2012. Sensory profiling, the blurred line between sensory and consumer science: A review of novel methods for product characterization. Food Res. Int. 48:893-908.

Veiga, P. G., R. L. Cunha, W. H. Viotto, and A. J. Petenate. 2000. Caracterização química, reológica e aceitação sensorial do queijo petit suisse brasileiro. Food Sci. Technol. (Campinas) 20:349-357.

Worch, T. 2013. PrefMFA, a solution taking the best of both internal and external preference mapping techniques. Food Qual. Prefer. 30:180-191. 